\title{
Efficiency Considering Credit Risk in Banking Industry, Using Two-stage DEA
}

\author{
*Hadi Ghafoorian, Melati Ahmad Anuar, NikIntan Norhan, Mohammed Ndaliman Abubakar, Fazel \\ Mohammadi Nodeh \\ University Teknologi Malaysia, Malaysia \\ ${ }^{*}$ Ghafoorian77@gmail.com
}

\begin{abstract}
The increased competition in the banking industry and banks' efforts to participate in new markets has affected bank performance and credit risk. Their presence in new markets and strong competition from other competitors today makes them face more uncertain situation. Given the importance of this issue, there are few studies about the efficiency calculated with regard to credit risk. Banking literature on this subject is poor. This paper introduces two-stage data envelopment analysis technique for estimation of their efficiency with regard to credit risk, its output and inputs in the first and second stage. Non-performing loans is output to proxy credit risk.
\end{abstract}

Keywords: Economic efficiency, credit risk, two-stage DEA

\section{Introduction}

In the past two decades, the world financial and credit crises affected in each three levels of the world, national and firm economic. As result the governments adopted a now rules for avoiding failed of firms. The managers are under pressure of stockholder that is paying more attention to credit risk. From fifteen years old, that Berger and De Young have claimed that in failed banks there is a negative correlation between efficiency and risk; Researchers became interested in the various aspects related to efficiency and credit risk. The indicators such as provisions for loans losses, problem loans or bad loans to measure credit risk have been exercised(Pastor, 2002). The reasons offered by Berger et al are valuable which the first one is having problem in the assessment of credit risk. They said inefficient banks have a bad management of cost. The second is nature of bad or problem loans that banks have to expend more resources regain primary sources before problem or bad loans. Specifically, this process is exacerbated by the adverse economic situation; which are beyond the bank's control. The last reason is without an adequate assessment of loan applicants. It means, the loan is paid in order to increase profits is to reduce the primary sources of banks (Berger \& DeYoung, 1997).

The importance of credit risk is resulted measuring risk-adjusted efficiency on banking industry by researchers (Berg, Førsund, \& Jansen, 1992; Hughes, Lang, Mester, \& Moon, 1996; Hughes \& Mester, 1993; Mester, 1994a; Mester, 1996). Nevertheless, the method used is unsuitable for two fundamental reasons. Because majority of studies attempt to obtain risk-adjusted efficiency measures by introducing the measurement of credit risk as bad loans. In addition, other point is that not all loans have the same probability of being recovered. Unlike parametric models, in which incorporation of environment variables is immediate, in DEA this is a field in which research is still being done and about which there is no consensus. The proposals are very varied and can be classified into methods of one, two and three stages(Pastor, 2002). We discuss about DEA models (two-stage) that have been developed based on different views in the following paragraphs.

\section{Background of Study}

Settings of supply chain have been examined by using various DEA models by scholars. Understanding an issue that estimation of efficiency with having overview resulted really different than looking the part view is very substantial. Two-stage processes has been presented by Chen and Zhu (2004), this DEA twostage model has been considered efficiency of each part of process and overall.( Chen \& Zhu, 2004; Zhu, 2003). The game theoretic structure is foundation a number of supply chain approaches that they are two principal models. The first is a non-cooperative model and the second is a cooperative model. The noncooperative model is constructed on this assumption that buyer is follower and seller is leader (Liang, Cook, \& Zhu, 2008; Liang, Yang, Cook, \& Zhu, 2006). The leader's score of efficiency is calculated as first stage while in the second stage follower's score of efficiency is estimated. With regard, this limitation that score of efficiency in stage one must be unchanged after using multipliers. This new model is a parametric 
non-liner programming. the general concept of DEA has been used with two-stage processes for the cooperative game model (Cook, Liang, \& Zhu, 2010). One of important research area in data envelopment analysis is analyzing of factors contributing to efficiency. For example, the regresses of DEA scores has been used for identification key performance drivers in school as socioeconomic factors. in the first , productivity scores was calculated and in the second stage was tried to find correlate numerous explanatory variables with the scores of efficiency in second stage that earned during two decades but data envelopment analysis is used for explanations of productivity differences by ad hoc speculations(Cooper, Seiford, \& Zhu, 2011).

The contextual variables that are affecting on efficiency are evaluated by regard present appropriate estimation methods and a diversity of DGPs and statistical tests under each DGP (Banker and Natarajan, 2008, 2009). Two different two-stage methods were developed by Banker and Natarajan (2008). The first method consists of DEA in the first stage and then the regression analysis will used in the second stage. In contrast, the maximum likelihood estimation has been applied as second stage of second method although DEA has been used in the first stage of this method. Independence among contextual variables and inputs is one of the important points referred although; the relationship between contextual variables is acceptable. The results of Monte Carlo simulation has shown the two-stage method of DEA with maximum likelihood, regression, of To bit are suitable methods for estimating the impact of the contextual variables on efficiency (Banker \& Natarajan, 2008). In settings of many data envelopment analysis (DEA), the intermediate measures have been consisted in DMUs by two-stage processes. For instance, a two-stage process has been used to estimate the marketability and profitability of commercial banks in US. In their research, labor and assets were inputs for measuring of profitability, and profits and revenue were the outputs. in the second stage that marketability has been put, earnings per share, and market value returns is used as outputs while revenue and profits is applied as inputs (Seiford \& Zhu, 1999). Similarly, A two-stage method has applied by Kao and Hwang (2008) where operating and insurance expenses was used to generate premiums in the first stage and in the second stage, underwriting and investment profits in 24 nonlife insurance companies(Kao \& Hwang, 2008). In addition, there are more examples to show the importance of two-stage models such as the relation between information technology and efficiency(Chen, Liang, Yang, \& Zhu, 2006; Chen \& Zhu, 2004; Wang, Gopal, \& Zionts, 1997), analyzing of performance Baseball teams (Sexton \& Lewis, 2003), and many others.

In all the examples above, there are joint specifications in two- stage processes for DMUs under evaluation. Outputs that was used in the first stage then was used inputs in the second stage. The inputs in the second stage or the outputs from the first stage have been called intermediate measure. A considerable point in this case is that the intermediate measures come from output in the first stage and are the only inputs to the second stage. In fact, there are no extra independent inputs to that stage. Although there are some DMUs with network structures and other kinds of two-stage that the new inputs are added to the second stage extra to the intermediate measures. Con see Liang et al 2006 and Gaski (1984). In the model of Gaski, the second stage not only has some input firs stage but also has some additional inputs(Gaski, 1984). And also there are models more than two-stage(Shang, Hung, Lo, \& Wang, 2008; Shang, Hung, \& Wang, 2008). Shang et al. (2008a) and Shang et al. (2008b) used three DEA model for estimation of performance of hotel. There are some study base on network DEA and slack- based network approach The network DEA approach that include more than two-stage( Färe \& Grosskopf, 1996; Färe, Grosskopf, Logan, \& Lovell, 1985; Tone \& Tsutsui, 2009). Newly, DEA developed by different views (Castelli, Pesenti, \& Ukovich, 2010; Chen, 2009; Cook, Zhu, Bi, \& Yang, 2010; Li, Chen, Liang, \& Xie, 2012; Mostafa, 2009; Wu, Yang, \& Liang, 2006; Yu \& Lin, 2008).

\section{Efficiency and Credit Risk in Banking Industry}

Investing in a debt security and bank loan are important factors that make risk in banking industry. This type of risk is called credit risk. In other words, the credit risk is risk of borrower default. In order to solve this potential problem, however, banks have created new financial derivatives; credit risk remains one of the most serious challenges facing the banks. However, banks and investors are able to stand against movements of quality of the borrower but credit risk is one of the biggest risks to the banking system(Neal,1996). The risk of loss of principal or loss of a financial reward is stemming from a borrower's failure to repay a loan or otherwise meet a contractual obligation. Credit risk arises whenever a borrower is expecting to use future cash flows to pay a current debt. Investors are compensated for assuming credit risk by way of interest payments from the borrower or issuer of a debt obligation (Shah, Ullah, \& Khalid, 2012). Credit risk is closely tied to the potential return of an investment, the most notable 
being that the yields on bonds correlate strongly to their perceived credit risk(Allen, 2003). The higher the perceived credit risk, the higher the rate of interest those investors will demand for lending their capital. Credit risks are calculated based on the borrowers' overall ability to repay. This calculation includes the borrowers' collateral assets, revenue-generating ability and taxing authority(Berger \& Udell, 1994).Credit risk is the probability of loan repayment. In fact, credit risk is the commitment of borrowers to repay their bank loans or debt. Default occurs when the borrower cannot being committed to its financial obligations and not able to repay bank loans. By default, the lender banks are at risk because they cannot get all the payments that were promised(Alexander-Andrew, 2011).

The bad loan has been used as indicator for credit risk. In the earlier studies it has been made correction by extra variable including bad loans in the cost equation as an additional(Hughes \& Mester, 1993; Mester, 1994a, 1994b). Berger and De Young tried to addresses a little examined intersection between the bank efficiency and problem loan literature. They used Granger-causality techniques for testing their hypotheses. "The data suggest that problem loans precede reductions in measured cost efficiency; that measured cost efficiency precedes reductions in problem loans; and that reductions in capital at thinly capitalized banks precede increases in problem loans". They believe for prediction of future problem loans and problem banks, the cost efficiency will be a substantial indicator. Although their finding are vague concerning whether or not researchers should control for problem loans in efficiency estimation(Berger \& DeYoung, 1997). Pastor and Serrano (2005) in order to estimate the efficiency of 11 big banks in European countries adjusted for credit risk by using a parametric stochastic procedure. For the first stage, they calculate the efficiency and then use bad loans as indicator of credit risk. Their result show that credit risk impact on the profit efficiency and it is not important in cost efficiency(Pastor \& Serrano, 2005). Previous studies(Berger \& DeYoung, 1997; Williams, 2004)focus on the non-performing to total loans ratio (NPL) as a proxy for banks' credit risk. While the NPL is a widely used accounting indicator of banks' risk, this measure is subject to managerial discretion, focuses mostly on credit risk, and is backward looking. The two measures of bank risk are complementary: EDF is forward-looking and a broader measure of banks' risks, whereas NPL accounts for realized credit risk. In this study we used non-performing to total loans ratio on proxy of credit risk. This indicator was used in the previous study (Altunbas, Liu, Molyneux, \& Seth, 2000; Fiordelisi, Marques-Ibanez, \& Molyneux, 2011).

\section{Justification of Two-Stage DEA}

As mentioned, multistage stricture is common for estimation efficiency. Particularly, the multistage stricture is popular for estimation of efficiency in processing organizations(Cook, Zhu, et al., 2010). In this study, we assume the inputs in the first stage generate non-performing loans as output and this is input for second stage.

Figure 1: Credit based two-stage DEA model

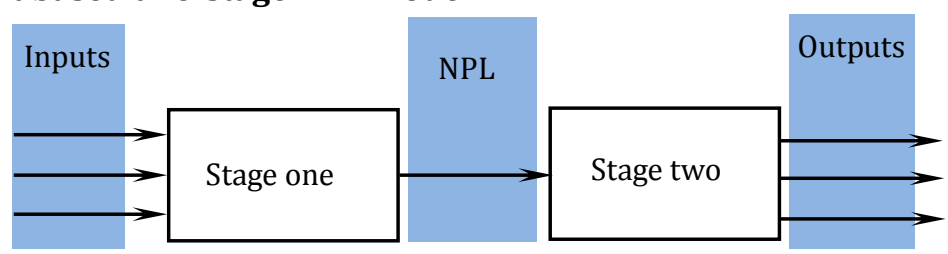

We consider a two-stage process that is show in Fig. 1, for each of a set of $n$ banks. We assume each $\operatorname{bank}_{i}(i=1,2, \ldots, n)$ andhavem inputs $x_{j i}(j=1,2, \ldots, m)$ to the first stage, and the output from the first stage is $N P L_{i}$ that is input for stage two. The final outputs from the banks are $y_{k i}(k=1,2, \ldots, r)$. This model is based the notion of pervious study (Y. Chen \& Zhu, 2004; Kao \& Hwang, 2008). In this approach, there are two efficiency score. That is denoted $e_{i}^{1}$ for first stage and $e_{i}^{2}$ for second stage. Base of traditional DEA model of Charnes et al (1978) and using the constant returns to scale (CRS), we have:

$$
\begin{aligned}
& e_{i}^{1}=\frac{v N L P_{i}}{\sum_{j=1}^{m} w_{j} x_{j i}} \text { And } e_{i}^{2}=\frac{\sum_{k=1}^{r} u_{k} y_{k i}}{\tilde{v} N P L_{i}} \\
& \text { Where; } \quad v, \tilde{v}, w, u \geq 0
\end{aligned}
$$

It is clear; they are two scores of efficiency, for stage one and stage two respectively and it is reasonable if the overall efficiency is defined with following equation: 


$$
E_{i}=\frac{1}{2}\left(e_{i}^{1}+e_{i}^{2}\right)
$$

According to the above equation the central equation for estimation of bank efficiency with considering credit risk will be:

$$
\begin{gathered}
\operatorname{Max} E_{i}=\frac{1}{2}\left(\frac{v N P L_{i}}{\sum_{j=1}^{m} w_{j} x_{j i}}+\frac{\sum_{r=1}^{r} u_{k} y_{k i}}{\tilde{v} N P L_{i}}\right) \\
\text { S.t: } \frac{v N L P_{i}}{\sum_{j=1}^{m} w_{j} x_{j i}} \leq 1
\end{gathered}
$$

And $\frac{\sum_{k=1}^{r} u_{k} y_{k i}}{\tilde{v} N P L_{i}} \leq 1$ for each banks

$$
v, \tilde{v}, w, u \geq 0
$$

\section{Conclusion}

Economic and financial crises and the increasing interest of banks present in new markets, despite growing competition have led managers to use new models to calculate performance. The traditional model cannot meet the needs of today. In this study, the issue of credit risk in the banking system is the most significant risk is considered in assessing performance. We proposed a two-stage model of data envelopment analysis to measure the relative efficiency of banks with respect to credit risk.

Acknowledgment: We would like to thank the Universiti Teknologi Malaysia (UTM). This research work has been supported by UTM through IDF. The authors gratefully acknowledge the IDF financial support from Universiti Teknologi Malaysia.

\section{References}

Alexander-Andrew, V. (2011). The Effectiveness Of Credit Derivatives On Bank Holding Company Portfolio Management. Journal of Business \& Economics Research, 4(9).

Allen, S. L. (2003). Financial Risk Management: A Practitioner's Guide to Managing Market and Credit Risk (with CD-ROM) (119): Wiley.

Altunbas, Y., Liu, M. H., Molyneux, P. \& Seth, R. (2000). Efficiency and risk in Japanese banking. Journal of Banking \&amp; Finance, 24(10), 1605-1628.

Banker, R. D. \& Natarajan, R. (2008). Evaluating contextual variables affecting productivity using data envelopment analysis. Operations Research, 56(1), 48-58.

Berg, S. A., Førsund, F. R. \& Jansen, E. S. (1992). Malmquist indices of productivity growth during the deregulation of Norwegian banking, 1980-89. The Scandinavian Journal of Economics, 3, 211-228.

Berger, A. N. \& DeYoung, R. (1997). Problem loans and cost efficiency in commercial banks. Journal of Banking \& Finance, 21(6), 849-870.

Berger, A. N. \& Udell, G. F. (1994). Did risk-based capital allocate bank credit and cause a" credit crunch" in the United States? Journal of Money, Credit and Banking, 5, 585-628.

Castelli, L., Pesenti, R. \& Ukovich, W. (2010). A classification of DEA models when the internal structure of the Decision Making Units is considered. Annals of Operations Research, 173(1), 207-235.

Chen, C. M. (2009). A network-DEA model with new efficiency measures to incorporate the dynamic effect in production networks. European Journal of Operational Research, 194(3), 687-699.

Chen, Y., Liang, L., Yang, F. \& Zhu, J. (2006). Evaluation of information technology investment: a data envelopment analysis approach. Computers \& Operations Research, 33(5), 1368-1379.

Chen, Y. \& Zhu, J. (2004). Measuring information technology's indirect impact on firm performance. Information Technology and Management, 5(1), 9-22.

Cook, W. D., Liang, L. \& Zhu, J. (2010). Measuring performance of two-stage network structures by DEA: A review and future perspective. Omega, 38(6), 423-430.

Cook, W. D., Zhu, J., Bi, G. \& Yang, F. (2010). Network DEA: Additive efficiency decomposition. European Journal of Operational Research, 207(2), 1122-1129.

Cooper, W. W., Seiford, L. M. \& Zhu, J. (2011). Handbook on data envelopment analysis: Springer.

Färe, R., \& Grosskopf, S. (1996). Productivity and intermediate products: A frontier approach. Economics Letters, 50(1), 65-70. 
Färe, R., Grosskopf, S., Logan, J. \& Lovell, C. A. K. (1985). Measuring efficiency in production with an application to electric utilities. Managerial issues in productivity analysis. Kluwer-Nijhoff Publishing Boston, 2, 185-214.

Fiordelisi, F., Marques-Ibanez, D. \& Molyneux, P. (2011). Efficiency and risk in European banking. Journal of Banking \&amp; Finance, 35(5), 1315-1326.

Gaski, J. F. (1984). The theory of power and conflict in channels of distribution. the Journal of Marketing, 3 , 9-29.

Hughes, J. P., Lang, W., Mester, L. J. \& Moon, C. G. (1996). Efficient banking under interstate branching. Journal of Money, Credit and Banking, 28(4), 1045-1071.

Hughes, J. P. \& Mester, L. J. (1993). A quality and risk-adjusted cost function for banks: Evidence on the too-big-to-fail doctrine. Journal of Productivity Analysis, 4(3), 293-315.

Kao, C. \& Hwang, S. N. (2008). Efficiency decomposition in two-stage data envelopment analysis: An application to non-life insurance companies in Taiwan. European Journal of Operational Research, 185(1), 418-429.

Li, Y., Chen, Y., Liang, L. \& Xie, J. (2012). DEA models for extended two-stage network structures. Omega, 40(5), 611-618.

Liang, L., Cook, W. D. \& Zhu, J. (2008). DEA models for two-stage processes: Game approach and efficiency decomposition. Naval Research Logistics (NRL), 55(7), 643-653.

Liang, L., Yang, F., Cook, W. D. \& Zhu, J. (2006). DEA models for supply chain efficiency evaluation. Annals of Operations Research, 145(1), 35-49.

Mester, L. J. (1994a). Efficiency of banks in the third federal reserve district: Federal Reserve Bank of Philadelphia.

Mester, L. J. (1994b). How efficient are third district banks? Business Review, 1994, 1-3.

Mester, L. J. (1996). A study of bank efficiency taking into account risk-preferences. Journal of Banking \&amp; Finance, 20(6), 1025-1045.

Mostafa, M. M. (2009). Modeling the efficiency of top Arab banks: A DEA-neural network approach. Expert Systems with Applications, 36(1), 309-320.

Neal, R. S. (1996). Credit derivatives: New financial instruments for controlling credit risk. Economic Review-Federal Reserve Bank of Kansas City, 81, 15-28.

Pastor, J. M. (2002). Credit risk and efficiency in the European banking system: A three-stage analysis. Applied Financial Economics, 12(12), 895-911.

Pastor, J. M. \& Serrano, L. (2005). Efficiency, endogenous and exogenous credit risk in the banking systems of the Euro area. Applied Financial Economics, 15(9), 631-649.

Seiford, L. M. \& Zhu, J. (1999). Profitability and marketability of the top 55 US commercial banks. management science, 45(9), 1270-1288.

Sexton, T. R. \& Lewis, H. F. (2003). Two-stage DEA: an application to major league baseball. Journal of Productivity Analysis, 19(2), 227-249.

Shah, M., Ullah, H. \& Khalid, S. (2012). A Comparative Study of Credit Risk in Different Companies of Different Sectors in Pakistan. International Journal of Academic Research in Business and Social Sciences, 2(1).

Shang, J. K., Hung, W. T., Lo, C. F. \& Wang, F. C. (2008). Ecommerce and hotel performance: three-stage DEA analysis. The Service Industries Journal, 28(4), 529-540.

Shang, J. K., Hung, W. T. \& Wang, F. C. (2008). Service outsourcing and hotel performance: three-stage DEA analysis. Applied Economics Letters, 15(13), 1053-1057.

Tone, K. \& Tsutsui, M. (2009). Network DEA: A slacks-based measure approach. European Journal of Operational Research, 197(1), 243-252.

Wang, C. H., Gopal, R. D. \& Zionts, S. (1997). Use of data envelopment analysis in assessing information technology impact on firm performance. Annals of Operations Research, 73, 191-213.

Williams, J. (2004). Determining management behaviour in European banking. Journal of Banking \& Finance, 28(10), 2427-2460.

Wu, D., Yang, Z. \& Liang, L. (2006). Using DEA-neural network approach to evaluate branch efficiency of a large Canadian bank. Expert Systems with Applications, 31(1), 108-115.

Yu, M. M. \& Lin, E. T. J. (2008). Efficiency and effectiveness in railway performance using a multi-activity network DEA model. Omega, 36(6), 1005-1017.

Zhu, J. (2003). Quantitative models for performance evaluation and benchmarking: data envelopment analysis with spreadsheets and DEA excel solver (Vol. 51): Kluwer Academic Pub. 